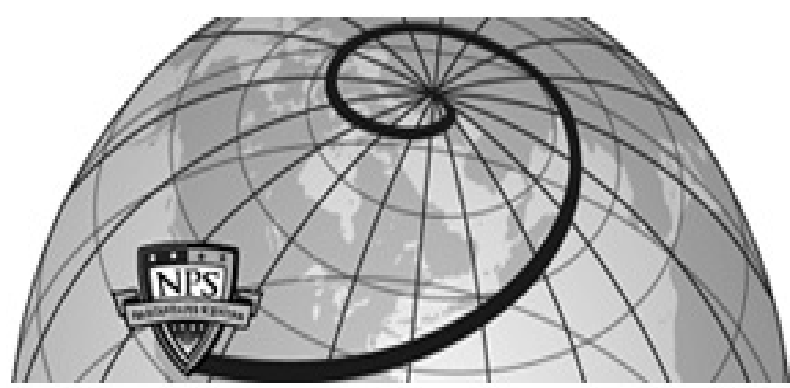

Calhoun: The NPS Institutional Archive DSpace Repository

\title{
Assessment of Technology in Organizations: Closed versus Open Systems Approaches
}

Rousseau, Denise M.

Academy of Management Review, 1979, Vol. 4, No.4, pp. 531-542

http://hdl.handle.net/10945/45983

This publication is a work of the U.S. Government as defined in Title 17, United States Code, Section 101. Copyright protection is not available for this work in the United States.

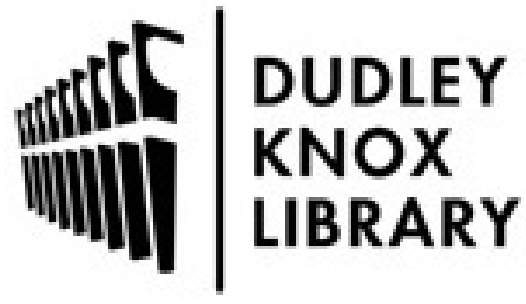

http://www.nps.edu/library
Calhoun is the Naval Postgraduate School's public access digital repository for research materials and institutional publications created by the NPS community. Calhoun is named for Professor of Mathematics Guy K. Calhoun, NPS's first appointed -- and published -- scholarly author.

Dudley Knox Library / Naval Postgraduate School 411 Dyer Road / 1 University Circle Monterey, California USA 93943 


\title{
Assessment of Technology In Organizations: Closed versus Open Systems Approaches
}

\author{
DENISE M. ROUSSEAU \\ Naval Postgraduate School
}

Technology is a multiphasic, multilevel input/output mechanism that is interdependent with its environment. Past research suggests that inconsistent assessments of technology may be attributed to examining different phases of the same transformation process. Past research has generally ignored input and output activities as well as critical energy exchanges between the technology and the environment. Technology can be assessed at several levels (individual job, subunit, and organization), which are interdependent, yet may reflect qualitatively different activities. A framework for assessing technology is derived from these multiple levels. This framework can be used to aid integration of research, to encourage more thorough assessment of technology, and to investigate the relations between the environment and technology.

Technology is a central concept in organization science. Yet, its application is problematic. In this paper, I question the traditional, closed systems approach used to study technology in organizations. I evaluate traditional methods for assessing technology and describe a framework that synthesizes past research and can guide future studies. Finally, I develop guidelines for future research that take into account changing issues in the study of technology, particularly those pertaining to the organization's environment.

\section{Technology as a Process of Transforming Inputs into Output}

Technology is generally defined as the application of knowledge to perform work. Because work today takes place primarily in organizations, modern technology is largely an organizational phenomenon. It is shaped by the needs of organizations to provide their environments with a product or

(C) 1979 by the Academy of Management $0363-7425$ service in exchange for capital, fuel, and other resources. It in turn shapes the effectiveness of the organization and the responses of its members.

Technology has been a central concept in orga- . nizational research and theory since the work of Woodward [1958, 1965]. Organizational researchers commonly define technology as the process of transforming inputs into output [Billings, 1977; Reimann, 1977; Rousseau, 1977]. This definition is consistent with both an open systems view [Katz \& Kahn, 1978] and an engineering one [Hancock, Macy, \& Peterson, 1978]. When treated as an inputoutput process, an organization's technology represents a sequencing of events involving admission of input (raw materials, people, knowledge) into the organization, conversion of this input into output through the application of skill and energy, and disposal of output into the environment. Technology may thus be conceptualized as having three major phases: input, conversion, and output.

To treat technology as an input-conversionoutput mechanism is to recognize the qualitatively 
different types of activities that make up the workflow in organizations and the interdependence among these activities. Thompson [1967] addressed the interdependence between conversion activities and input and output activities. He argued that all three are subject to organizational rationality: these activities must be appropriately geared to one another, acquired inputs must be within the scope of the conversion process, and the organization must have the ability to dispose of its product. The degree of interdependence among input, conversion, and output phases differentiates Thompson's technological types.

Although input and output activities are distinct, both can be assessed in two forms: as characteristics and as control functions. Input characteristics are attributes of the materials, information, or people brought into the organization, such as hardness of materials or diversity of inputs. Input control refers to those functions influencing the availability and distribution of inputs in preparation for conversion, such as stockpiling or screening. Similarly, output has two facets. Output characteristics are attributes of output following the completion of the conversion process, such as the number of different products or services and the type of output produced. Output control represents those mechanisms that influence the quantity or quality of output released to the environment, such as quality control procedures and stockpiling.

Conversion processes add value to the inputs (raw materials, clients, or information) through the abilities and capacities of both operators and equipment. In the conversion process, value is added by transforming inputs (as in manufacturing firms, schools, or hospitals) or by maintaining inputs (as in facilities caring for the severely disabled). The transformation of inputs such as raw materials or people adds value by altering their form or structure (physical or mental) in some desired way. In service organizations such as custodial-care facilities, value is added by meeting the needs of the client or patient to a degree difficult to achieve outside the organization.

Both input and output control mechanisms buffer the conversion process from its environment. Each performs smoothing and allocation functions. Smoothing in the input phase controls the flow of materials, information, or people into conversion and facilitates a constant rate of processing (e.g., by stockpiling materials). At the other end, smooth ing through output control affects the rate of produc entry to the environment (e.g., maintaining a large inventory). Allocation of input refers to the distribution of inputs to the appropriate conversion proces (e.g., sending patients to appropriate clinics). Allo. cation of output refers to the distribution of goods to markets or for further processing (e.g., sendin electronic components to assembly).

The characteristics and control functions associated with input and output activities may them selves be highly interdependent. For example, in put characteristics that are highly diverse (as foun in hospital emergency rooms) may lead to mor complex input controls than those found in work systems with homogeneous inputs. Similarly, out put varying in quality or quantity may require more elaborate output controls (e.g., in developing electronic component prototypes) than those found in less variable work systems.

Obviously, the environment influences this inputoutput mechanism. Organizational units (organiza. tions, subunits, job incumbents) perform both input and output functions at their boundary with the environment. Each processes materials from the environment and disposes of products to it Through input and output activities, organizational units may sense relevant changes in the environ ment and make appropriate adjustments. When hospital emergency room receives an unusuall high number of emergency admissions, the physician in charge may assign priorities for treatment certain patients or give less than standard care to some. Input characteristics may thus shape con version activities.

Similarly, output characteristics may also shape conversion activities. A community college offering a narrow range of evening courses (an output char acteristic) may have difficulty attracting student unless it increases the diversity of courses offered However, changes in courses may require corres ponding changes in faculty skills and expertise conversion characteristic). Thus, output character istics may also affect conversion activities and, like input characteristics, they are directly related environmental factors such as customer demand Environmental factors may therefore affect technol ogy in organizations through input and outpu activities.

Despite the role of input and output activities 
technology, past assessments of technology in organizations have been heavily conversion oriented. A review of 29 studies of technology in organizations (see Table 1) indicates that most of them consider technology in terms of the conversion process, particularly according to the degree or level of automation. Wieland and Ullrich [1976] have argued that emphasis on conversion processes at the expense of input-output activities reflects the continuing influence of scientific management on the way we conceptualize organizations. Despite the fact that Taylor [1947] did consider other dimensions of technology besides conversion characteristics, scientific management seldom addresses factors outside the unit of analysis (job or department). Studies of conversion processes in isolation from the influences of external factors reflect a static, closed systems view of technology. This view is inconsistent with both the widely accepted open systems view of organizations [Katz \& Kahn, 1978] and with the increasing attention being given to technology-environment interaction [Jelinek, 1977]. Although open systems approaches are not uniformly superior to closed systems ones [Kast \& Rosenzweig, 1972], they may be more appropriate in studying technology because of the dependence of the transformation process on the environment.

Many major criticisms of research on technology can be attributed to the closed systems approaches employed in technology research. Closed systems approaches ignore the multiple phases of activity that characterize technology, the interdependence among the levels at which these activities occur, and the dependence of technology on the environment. Research on technology has been criticized for inconsistent operationalizations [Stanfield, 1976] and unexplained shifts in levels of analysis [Lynch, 1974; Rousseau, 1978b]. Further, Shepard [1977] and Stanfield [1976] have criticized researchers for generalizing their conceptions of technology. Researchers often measure one facet of technology, such as routineness or automation, but then discuss their findings as if that facet represents the entire construct of technology. Yet, critics have argued that technology is too complex to be completely described by any one measure.

In response to the literature, I will argue that:

Apparently inconsistent operationalizations of technology actually reflect different phases of the transformation process defined here as technology. Although diverse operationalizations exist within phases, technological assessments generally reflect only a few dimensions, particularly at the organizational and subunit levels of measurement.

2. Different levels at which assessments are made represent different levels of interdependent activities in the organization's workflow. Technological characteristics at the individual level interact to characterize subunit technologies that in turn are subsumed in the organization's technology.

3. The construct of technology can be analyzed into components that are theoretically and operationally useful by identifying the phases and levels of measurement that the researcher assesses.

4. Technology in organizations is greatly influenced by the environment, particularly through its influence on input and output activities and on the types of technology adopted by the organization. Although theorists have recognized the technology-environment relation, researchers have not assessed technology in terms of the critical energy exchanges between the organization and its environment.

\section{Assessments of Technology In Organizational Research}

\section{Phases of Technology}

Researchers and theorists have been critical of the inconsistent operationalizations of technology in organizational research. Researchers seldom explicate their reasons for choosing a particular operationalization. Furthermore, almost half the studies reviewed here use unique measures of technology, making it difficult to integrate research. The table indicates, however, that researchers may not operationalize technology as diversely as critics claim. Virtually every study reviewed assessed technology, at least in part, in terms of the conversion process. Conversion process assessments predominate at the three levels of measurement generally employed in technological research: organizational, subunit, and individual.

The most striking differences in assessments are not within technological phases but between them. For example, output characteristic assessments (such as product change and type of product) reflect concepts that are qualitatively distinct from 


\section{Table 1}

\section{Assessments of Technology in Organizational Research}

INPUT CHARACTERISTICS Organization level:

None found
INPUT CONTROL

Organization level:

None found
CONVERSION

Organization level:

\section{Automation}

Classification into unit, mass, or continuous process - Woodward, 1958, 1965; Fullan, 1970; Zwerman, 1970; Peterson, 1975

Automation of equipment - Hickson et al., 1969 Inkson et al., 1970; Child \& Mansfield, 1972

Production continuity - Hickson et al., 1969; Child \& Mansfield, 1972

Use of production lines — Freeman, 1973

Extent of automation - Freeman, 1973

Classification of firms into custom, small batch, large batch, mass production, and continuous process technology - Khandwalla, 1974; Reimann, 1977

Amount of automation - Blau et al., 1976

Use of computers - Blau et al., 1976

\section{Complexity}

Ranking of technical complexity based on types of equipment, routines required to operate machines and workflow design — Form, 1972

Technical complexity - Blau et al., 1976

Other

Rigidity of workflow sequences - Hickson et al. 1969; Inkson, 1970; Child \& Mansfield, 1972

Interdependence of workflow segments - Hickson et al., 1969; Child \& Mansfield, 1972

Classification into long-linked, mediating, and intensive - Morrisey \& Gillespie, 1975

\begin{tabular}{|c|c|}
\hline $\begin{array}{l}\text { Subunit or } \\
\text { department level: }\end{array}$ & $\begin{array}{l}\text { Subunit or department level: } \\
\qquad \text { Automation }\end{array}$ \\
\hline $\begin{array}{l}\text { Standardization of } \\
\text { materials-Taylor, } 1971\end{array}$ & Automation of throughput - Taylor, 1971 \\
\hline & $\begin{array}{l}\text { Classification according to large batch and mass } \\
\text { production - Billings et al., } 1977\end{array}$ \\
\hline & $\begin{array}{l}\text { Classification as long-linked technology - } \\
\text { Billings et al., } 1977\end{array}$ \\
\hline & Automation - Billings et a., 1977 \\
\hline & Routineness \\
\hline & Routineness - Mohr, 1971 \\
\hline & $\begin{array}{l}\text { Classificatio according to routine, engineering, } \\
\text { and craft technologies - Grimes \& Klein, } 1973\end{array}$ \\
\hline & $\begin{array}{l}\text { Classification according to routine, mediating, } \\
\text { and non-routine technologies - Randolph \& Finch } \\
1977\end{array}$ \\
\hline & Standardization of care - Comstock \& Scott, 1977 \\
\hline
\end{tabular}

OUTPUT CONTROL

Organization level:

Specificity of output evaluation - Hickson et al., 1969; Inkson et al., 1970; Child \& Mansfield, 1972

Subunit or department level:

Performance feedbackTaylor, 1971
OUTPUT CHARACTERISTICS Organization level:

Output Changes

Number of product changes in last ten years- Harvey, 1968

Rate of industrywide productivity change Reimann, 1976

\section{Other}

Average number of different kinds of products offered during last ten years-Harvey, 1968

Type of substance produced (integral or dimensional)-Freeman. 1973

\section{Subunit or}

Analyzability of material-Mohr, 1971 conversion assessments (such as automation and zomplexity). Within each phase, however, operaionalizations are often not only similar but also conceptually related. For example, the predomihant conversion process assessments at the subunit level, automation and routineness, may be ighly related. Use of computerized control proc- esses generally involves highly routine work operations. Within technological phases, conceptualizations may thus be somewhat homogeneous. Inconsistencies in assessments of technology may actually reflect assessment of the different phases of the input-output process. 


\section{Table 1 (Continued)}

INPUT CHARACTERISTICS

Subunit or department level:

INPUT CONTROL

Subunit or

department level:

CONVERSION

Subunit or department level:

Use of Discretion

OUTPUT CONTROL

Subunit or

department level:
OUTPUT CHARACTERISTICS

Subunit or department level

Classification according to long-linked, mediating

and intensive technologies - Mahoney \& Frost, 1974

Rousseau, 1977, 1978a, 1978

Need for nursing judgment - Combstock \& Scott, 1977

Number of choice alternatives - Comstock \& Scott 1977

Other

Complexity - Mohr, 1971

Uniformity - Mohr, 1971

Task interdependence - Mohr, 1971

Noise level-Mohr, 1971

Workflow rigidity - Billings et al., 1977

Type of nursing care - Comstock \& Scott, 1977

Individual or job level: Variability Variability-Van de Ven \& Delbecq, 1974

Variety of health problems-Overton et al., 1977

Other

umber of patients equiring frequent observation-Overton et al., 1977

Frequency of emergency - Overton et al., 1977

Patient age groupsOverton et al., 1977

Length of hospital history requiredOverton et al., 1977
Individual or job level: Individual or job level:

Predictability

Predictabiliyt of hospital stay-Overton et al., 1977

Predictability of events - Lynch, 1974

Predictability of work demands-Bell, 1967 Lynch, 1974

\footnotetext{
Amount of discretion - Bell, 1967; Hrebiniak, 1974

Extent of responsibility - Bell, 1967

Routineness - Hage \& Aiken, 1969; Hrebiniak, 1974; Lynch, 1974

Complexity - Hrebiniak, 1974

Uniformity - Hrebiniak, 1974

Analyzability - Hrebiniak, 1974

Interdependence - Hrebiniak, 1974; Lynch, 1974; Overton et al., 1977

Understanding - Hrebiniak, 1974

Insufficient knowledge - Lynch, 1974

Difficulty.-Van de Ven \& Delbecq, 1974; Bell, 1967

Job characteristics (autonomy, variety, feedback. task significance, task identity, dealing with others) - Rousseau, 1978a

Use of technical equipment - Overton et al., 1977

Specification of patient goals - Overton et al. 1977

Differences in nursing care - Overton et al., 1977

Use of problem solving - Overton et al., 1977

Socio-psychoiogical care - Overton et al., 1977
}

Individual or job level:

Dependence on patient feedback-Overton et al. 1977
Individual or job level:

None found
The predominance of conversion process assessments has, to some extent, led to neglect of the other phases that contribute to the performance of work in organizations. The infrequent assessment of input and output phases may be linked to the ypes of organizations studied. On the one hand, all studies assessing technology in terms of input characteristics were conducted in service organizations where the inputs processed are human [e.g., Mohr, 1971; Overton, Schneck, \& Hazlett, 1977; Van de Ven \& Delbecq, 1974]. It is likely that researchers believe human inputs are more salient or 
important than nonhuman ones. Thus, they give more attention to input characteristics in studies of service organizations than in studies of manufacturing firms. On the other hand, all studies assessing output characteristics were conducted in manufacturing organizations [Freeman, 1973; Harvey, 1968; Reimann, 1977]. In such organizations, the nature of the product may be more tangible and easier to assess than in service organizations. However, although the type of organization studied may influence the ease of assessing certain technological phases, it is likely that input, conversion, and output phases are relevant to the accurate assessment of technology in all organizations.

\section{Levels of Measurement}

Researchers measure technology at the multiple levels through which work flows in the organization: the individual job, subunit, and organizational levels. These multiple levels of activity reflect efforts of organizational units (members, departments, and the entire organization) to produce a product or service. These levels are highly interdependent. Subunits are composed of individual jobs in much the same way that groups are composed of individual members. Groups may be qualitatively different from their individual members because of interactions among members. Subunit technology differs qualitatively from the individual jobs within each department. It is not simply the aggregation of individual jobs. Subunit technology reflects both characteristics of these jobs and the interactions among them. Similarly, the many subunits or departments within an organization interact to create an organizational technology. However, although researchers have examined the problems of coordination between technologies within a given level - such as between subunits [Lawrence \& Lorsch, 1969], there has been little research on the interdependence between different levels of activities (i.e., between jobs and departments or departments and the organization).

Research on technology in organizations has generally given insufficient attention to the level at which technology is assessed. Although almost half of the studies reviewed here assess technology at the organizational level, many others assess it at the subunit or individual level. Yet, researchers seldom explain their choice of a particular measure- ment level. Those studies looking at differences in employee affective responses have assessed technology at the organizational [Form, 1972; Peterson, 1975] and subunit [Rousseau, 1977, 1978a] levels. Studies assessing the dimensionality of technology measure its characteristics at the individual level [Lynch, 1974; Overton, Schneck, \& Hazlett, 1977], perhaps because it is easy to assess diverse technological characteristics through questionnaires.

However, the majority of technology research pertains to the technology-structure relationship. This relationship has been investigated through assessments at all three levels: organizational [Blau, Falbe, McKinley, \& Tracy, 1976; Harvey, 1968; Hickson, Pugh, \& Pheysey, 1969; Inkson, Hickson, \& Pugh, 1970; Woodward, 1958, 1965; Zwerman, 1970], subunit [Grimes \& Klein, 1973; Mohr, 1971], and individual [Bell, 1967; Hage \& Aiken, 1969; Hrebiniak, 1974]. Inasmuch as researchers have examinéd the structure-technology relation through all three levels of measurement, it can be inferred that the research question does not necessarily dictate measurement level.

Levels of measurement do, however, seem to affect both the technological phases studied and the diversity of measures used. Researchers most frequently assess both input characteristics and input control at the individual level. In contrast, they assess output characteristics at the organizational level. Additionally, assessments of the conversion processes are most heterogeneous at the individual level and least so at the organizational level. Assessments at the individual level, because they reflect employees' descriptions of their jobs, are very diverse, ranging from dimensions such as routineness and automation to difficulty and understandability.

The facets of technology measured generally grow more diverse as we move from macro to micro levels. This increasing diversity suggests that researchers do disaggregate the concept of technology as they shift from global macro-level descriptions of technology to specific micro descriptions of jobs. This increasing diversity may also be due to the ease of assessing concepts through questionnaires, which are frequently used at the individual level. However, disaggregation of technological assessments at the individual job level 
raises the issue of whether it is also possible to disaggregate the more global concepts of technology used at the organizational and subunit levels.

\section{Disaggregation}

Critics agree that the term "technology" is used ambiguously [Shepard, 1977; Stanfield, 1976]. The term has come to mean anything from routineness [Hage \& Aiken, 1969] to the hardness of materials [Rushing, 1968]. Both Stanfield and Shepard propose disaggregation of the construct of technology into more restricted concepts whose meanings more accurately reflect the specific technological characteristics assessed.

Disaggregation is necessary for precision in interpreting technology research. Yet, organizational theorists such as Jelinek [1977] have argued persuasively for multivariate assessments of technology. Further, to accurately portray technology, it may be necessary to assess multiple phases across multiple levels of activity. Multivariatemultilevel assessment and disaggregation may seem to conflict. However, comprehensiveness and precision can both be achieved by the disaggregation of technology assessment according to the phases and levels of measurement reflected (Figure 1).
The three levels of measurement and five phases of the transformation process discussed here can constitute a framework for technology assessment and disaggregation. Specification of technological phases employed in both research and theory recognizes the qualitatively different activities that constitute technology and may encourage more thorough assessment of nonconversion phases. Despite their interdependence, the phases of technology are distinct and may be differentially related to variables of interest to researchers. Clear specification of levels of measurement is also needed. Since qualitatively different levels of activity exist within an organization's technology, isomorphism among levels cannot be assumed. For example, output control mechanisms at the individual level (e.g., feedback from the job) may not be identical to those at the organizational level (e.g., quality control units). However, as I pointed out earlier, researchers have given little attention to the level at which technology is measured, despite the fact that virtually every technological issue (e.g., the technology-structure relation, the effect of unit characteristics on employee responses) has been examined using several levels of measurement. An explanation of the level chosen will help both researchers and theorists explore the interde-

\section{Phases}

Levels

Organization

Subunit

Individual

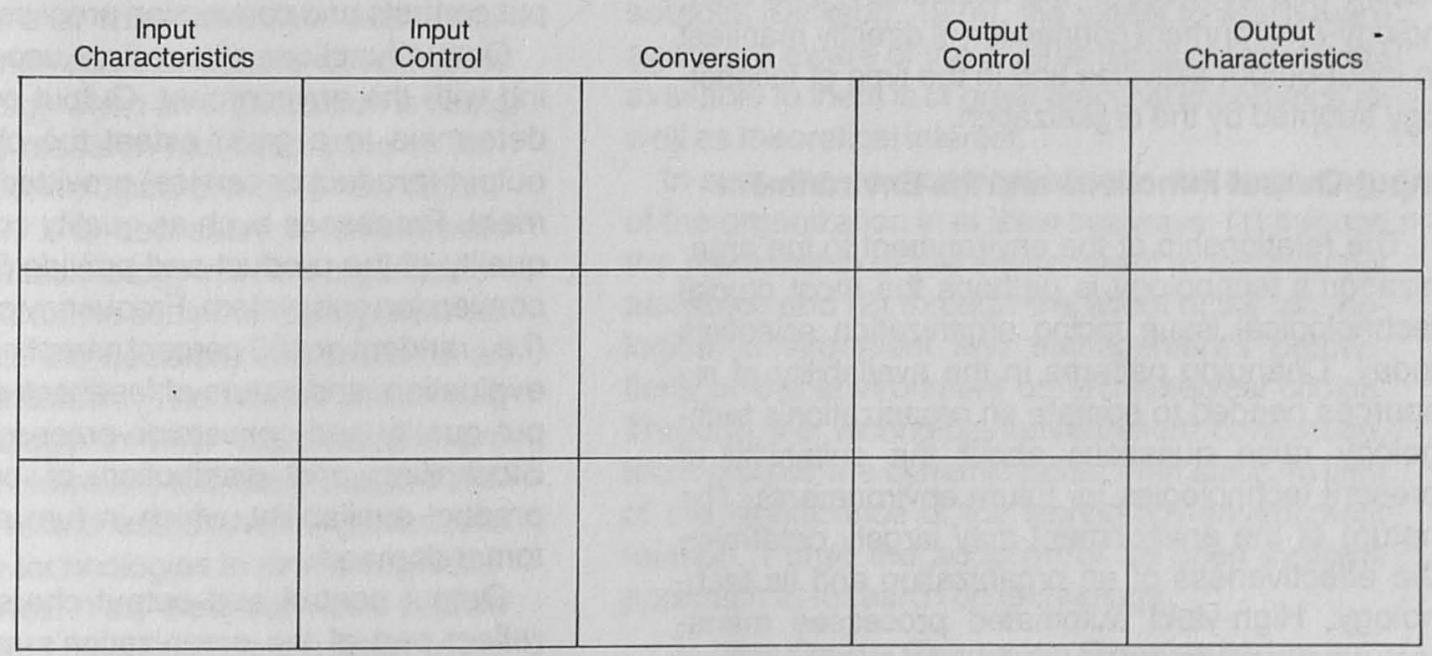

Figure 1

Framework for Assessment of Technology in Organizations 
pendencies among these levels. By discussing technology in terms of specific phases and levels, they may find it easier to integrate findings and to recognize their limitations.

Complete disaggregation of technology into its operational definitions, such as those in Table 1, may make the technology literature difficult to integrate. However, disaggregation according to a theoretical framework, such as that presented here, not onlly encourages clearer specification of the mature of the assessments made but also draws attentiom to those technological phases and levels of activity that are underrepresented in research. Disaggregation according to a theoretical frameworlk may increase our awareness of how adequately we are sampling the domain of that construct we tentm "technology."." To disaggregate without a theory conveying a sense of the interrelations ammeng part's is akin to having three blind men describe am ellephant [Roberts, 1970]. It is far easier to neoginize the impllications of a part when one has a sense of the whele.

\section{The Technology-Environment}

\section{Connection}

The firamework fior technology assessment disculssed above is nooted im the bellief that technology is a dyymamic and open process, and that organizatifiemall dependence on the environment shapes the mathure and activivities of the technology. The techmollogy-envintomment connection is directly manifest im imputut-oultopult activivities and in the type of technologyy adtopterd byy the organization.

\section{linput-Output Functions and the Environment}

The rielationsthip of the enviromment to the orgamizzatiom's terchmollogyy is perthaps the most crucial terchmnological issule flacing organization scientists troctaly. Chmanging pattlentms im the availlabilitity of resounces meeded to operathe am organizzation's techmollogyy niaise questions aboutt the suitabilitity of

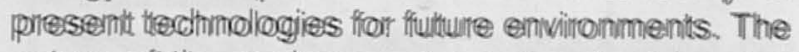

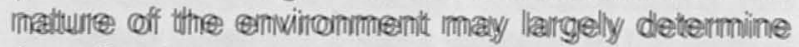
the effiectivemess of am organization and itts tech-

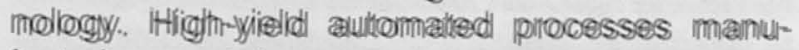

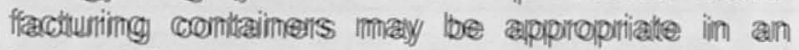

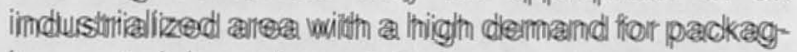
ingy matherials and comsistemt access to paper pulp.
However, they may be inappropriate in a newly industrialized area with smaller demand and irregular availability of raw materials. Here, small-scale batch production of containers may suffice. Technological characteristics suited to one environment may not be to another.

In organizations, input and output functions are directly related to the environment. According to the principle of technical rationality [Thompson, 1967], input-output functions buffer the conversion process by dealing with environmental uncertainty. When the environment is complex, organizational inputs such as materials or clients may be quite diverse. When diverse inputs are required, elaborate control mechanisms are needed. Automobile manufacturers, for example, require stockpiles of parts to provide a regular supply of materials for assembly. To further ensure the availability of materials, feeder industries are often subsidiaries of the major auto companies, increasing the organization's control over inputs. Organizations without elaborate input control mechanisms are often unit or batch production firms with conversion processes flexible enough to deal directly with environmental uncertainty by altering production methods when needed. The adequacy of input control affects the flexibility required in the conversion process and the amount of discretion required of the human operator. However, little research has been done on the effectiveness of various combinations of input controls and conversion processes.

Output functions also reduce uncertainty in dealing with the environment. Output controll activities determine to a great extent the character of the output (product or service) provided to the environment. Processes such as quality controll affifect the quality of the product and provide feedback to the conversion subsystem. Frequency of quallity cointrol (i.e., random or 100 percent sampling)), specifificity of evaluation, and nature of feedback shape botth output quality and conversion-process efffectiveness. Stockpiling and distribution of products shape product availability, which in turm mayy affiect customer demand.

Output controll and outputt characterristics each reflect part of the organization's manket stinathegy. The quality and availlabilitity of products as well as their type and inumber reflect the nichthe im the Imariket the organization seeks to imaintaim orr fifll. Am ellec- 
tronics firmm, ffor example, may adopt the strategy of producing llow-cost, diverse products of marginal quality. Another electronics firm may focus on the high, reliabilitity of a few products. Each strategy is associatted with a diffierent type of market and involves diffierent output functions that in turn shape the conversion subsystem. Strategies organizations emplloy to respond to environmental demands may greatlly affiect the choice of technology.

\section{Technological Choice}

Techinology is widelly thought to reflect a strategy the organization uses to deal with its environment [Newman, 19711; Wieland \& Ullirich, 1976]. As a manifestation of strategy, technology reflects a choice about the appropriate ways of providing a product or service. Techinology is not a given. It reflects chooices made by managers. Like any choice, it refilects the altiernatives the decision maker identififies, the perceived consequences of these alliermativives, and the values associated with them. Moreover, market conditions, costs, and competition infiluence the feasibility of various alternatives [Rousseau, 1978c].

Organizational theorists [Child, 1972; Montanari, 1978] have argued that both the technology and the structure of the organization are shaped largely by strategic chroices made by managers. Montanari focuses specififically on decisions to change existing technologies and trealts the existing technology as a contextulall factior that may constrain such decisions. He does mot address factors affecting the choice of technology when an organization is being established. Littile research has been done on factors infliuenciing technollogical choice in new organizations. Howwever, it is mecessary to differentiate between choice of technology in a new organization (when priior investument in equipment and personnel does nott comsistraim the decision)) and choice in an establisthed organization. The factors influencing choice of technology in new organizations are largely unikmown. However, it is likely that technologies in both mew and established organizations are influenced by technologies in similar organizations and industries. Yet, theorists have seldom considered the technological characteristics of the environment itsselfi.

Techmologicall environment, the nature of the technology in the larger industry or society, has been discussed by Katz and Kahn [1978] as an environmental inflluence on the organization and its choice of techinology. Students of technology [e.g., Ellull, 1963] have llong viewed the technological millieu of society as a potent influence on the processes adopted by production units (which may be indlividuals as well as organizations). Thus, the technological environment may greatly affect the technology chosen by organization members.

Because littlle research has been done on technological choice, we know littlle about how managers acquire information regarding available technologies (e.g., through trade journals, equipment suppliers, personal experience), their perceptions of available technologies, and the factors influencing their assessments of the suitability of these technologies. Because the organization interacts with the environment through its members' perceptions, particularly those of management, research on what managers consider to be appropriate technologies for their organizations may provide insight on technologicall change within organizations and industries. Within an industry, there are many ways of combining equipment, personnel, and resources to form a technology. Each combination reflects a technological alternative that management might adopt. Given the current concern for developing and implementing less capital-intensive ("alternative") technologies in response to changes in the availability of resources [Dickson, 1974], the extent to which managers are aware of the diverse types of technology availlable to them is of great practical importance as well as theoretical interest.

In sum, the environment shapes the technology of the organization in at least two ways: (1) through the relationship of the environment to input-output activities, and (2) through the effect of the technological environment and management's perceptions of the environment on technological choice. Through the technology-environment connection, technologies are dynamic rather than static. In light of the significance of the technology-environment reiation, I urge the adoption of an open systems approach to research on technology.

\section{An Open Systems Perspective To Technology Assessment}

It is common to argue for an open systems ap- 
proach to research within an area such as organizational behavior. Technology, as a process of transforming input into output, is virtually by definition open and responsive to environmental influences. An open systems approach to technology assessment would involve detailed assessment of input and output activities, with an emphasis on transactions between organizational units (members, subunits, and organizations) and their respective environments. However, as discussed above, current technology assessment in organizational research reflects a largely closed systems view, focusing on the conversion process while generally neglecting input and output activities. Furthermore, despite attempts to assess input and output functions, the indices employed seldom reflect the critical energy exchanges that must occur between the organization and its environment for the transformation to continue.

Because all organizations import energy from their environments and return some product or service [Katz \& Kahn, 1978; Thompson, 1967], all organizations are dependent on their environments. Owing to this dependency, technological effectiveness is often environment-specific. An effective technology in one environment may be inappropriate in another, not because of an inherent problem in the technology, but because of the environment's direct influence on input and output activities. A highly automated conversion process, for example, may be effective when a stable supply of raw materials and fuel is available but ineffective when input availability fluctuates.

Despite the significant influence of environment on technology, assessments of technology in organizational research seldom include the types of technological characteristics that may be most susceptible to environmental influences. These characteristics may be highly important to organizational effectiveness. Use of resources is one such characteristic. When measured as rate of fuel consumption (a conversion process characteristic) or substitutability of types of fuels or raw materials (an input characteristic), use of resources may be an important technological predictor of organizational effectiveness, particularly as availability of fuel and raw materials fluctuates.

The closed systems approach to technology assessment in organizational research reflects in part an assumption that the organization's environment is relatively static. Despite the fact that the environments of modern organizations have never been static, such a view made more sense in the past than it does now, with our ever-increasing concern over fuel shortages, changing values of the labor force, and economic uncertainty. An open systems approach to assessing modern technology is becoming increasingly important as the value of technology in adapting to the environment becomes apparent. In response to the need for environment-oriented evaluations of technology, a number of criteria are suggested here:

Input characteristics: substitutability of one form of raw material for another, substitutability of types of fuel, availability of inputs (fuel, raw materials, labor).

Input control: adaptation of inputs to available treatments, storage of fuel or raw materials.

Conversion: flexibility in response to changing inputs, rate of energy consumption per unit produced (or per client), utilization of capacity.

Output control: waste disposal, costs of output distribution, storage and stockpiling.

Output characteristics: perishability, durability.

These are some of the many possible criteria for evaluating phases of technology that reflect the interaction of technology and environment. By adopting an open systems approach to technology assessment (by assessing technology at its many phases and levels, and by using measures sensitive to environmental constraints and influences), we will be better able to describe the process of transforming input into output and to understand the crucial interaction between technology and environment.

\section{Summary and Recommendations}

Past research on technology generally has reflected static, closed systems thinking. It has lacked a systematic framework for technology assessment and is difficult to integrate. Despite problems in assessing it, however, technology has become a central concern of organization scientists and of scientists in general as its relation to the environment has become more evident. Modern technology is an organizational phenomenon, both an outgrowth and a cause of the development of complex organizations. The assessment framework pro- 
posed here represents one approach to mapping the domain of technology in organizations. Moreover, it can provide a basis for research evaluating both the relationship of technology to the environment and traditional concerns such as the links between technology and structure.

In this critique of technology assessment, I have suggested that the environment has been neglected. As a remedy, I recommend two lines of research:

Research on technological choice, particularly through studies conducted in new organizations. This research should examine, among other things, the entrepreneurs' perceptions of available and appropriate technologies. If organizational environments become increasingly turbulent owing to changes in resource availability and resulting economic fluctuation, identifying the factors that affect adoption of technology in new organizations may be the key to developing effective organizations and appropriate technologies in the future. In established organizations, research is needed on the factors affecting technological change, such as the value and perceptions of managers, engineers, and the research and development staff. Perceptions of the environment and beliefs about the availability and appropriateness of different technologies need to be explored.

2. Research on the relationship between technology and organizational effectiveness, particularly when environmental characteristics are examined as potential mediators of this relationship. Such research requires assessment of all phases of the technological process as well as assessments of the environment. Furthermore, future assessment of technology may broaden our knowledge of the construct by including more detailed measures of input and output activities. Such measures may be more sensitive to environmental influences than traditional conversion-oriented measures.

Organization scientists study technology because of its potential influence on organization structure and on individual job experiences. Yet, equally important are the role of technology as both an outgrowth and cause of the environment in which it is located, and the joint influence of technology and environment on organizational effectiveness. An open systems approach to technology assessment is necessary to understand the crucial interaction between technology and the environment.

\section{REFERENCES}

Bell, G. D. Determinants of span of control. American Journal of Sociology, 1967, 73, 100-109.

Billings, R. S., Klimoski, R. J., \& Breaugh, J. A. The impact of change in technology on job characteristics: A quasi-experiment. Administrative Science Quarterly, 1977, 22, 318-339.

Blau, P. M., Falbe, C. M., McKinley, W., \& Tracy, P. Technological organization in manufacturing. Administrative Science Quarterly, 1976, 21, 20-40.

Child, J. Organizational structure; environment, and performance: The role of strategic choice. Sociology, 1972, 6, 1-22.

Child, J., \& Mansfield, R. Technology, size, and organization structure. Sociology, 1972, 6, 369-393.

Comstock, D. E., \& Scott, W. S. Technology and the structure of subunits: Distinguishing individual and work group efforts. Administrative Science Quarterly, 1977, 22, 177-202.

Dickson, D. The politics of alternative technology. New York: Universe Books, 1974.

Ellul, J. The technological order. In C. F. Stoner (Ed.), The technological order. Detroit: 1963.
Form, W. H. Technology in social behavior of workers in four countries: A sociotechnical perspective. American Sociological Review, 1972, 37, 727-738.

Freeman, J. H. Environment, technology, and the administrative interests of manufacturing organizations. American Sociological Review, 1973, 38, 750-763.

Fullan, M. Industrial technology and worker integration in the organization. American Sociological Review, 1970, 25, 10281039.

Grimes, A. J., \& Klein, S. M. The technological imperative: The relative impact of task unit, modal technology, and hierarchy on structure. Academy of Management Journal, 1973, 16, 583597.

Hage, J., \& Aiken, M. Routine technology, social structure, and organizational goals. Administrative Science Quarterly, 1969, 4, 366-376.

Hancock, W. M., Macy, B. A., \& Peterson, S. R. The measurement of technology and its potential. Ann Arbor, Mich.: Institute for Social Research, The University of Michigan, 1978. 
Harvey, E. Technology and the structure of organizations. American Sociological Review, 1968, 33, 247-259.

Hickson, D. J., Pugh, D. S., \& Pheysey, D. C. Operations technology and organization structure: An empirical reappraisal. Administrative Science Quarterly, 969, 14, 378-397.

Hrebiniak, L. G. Job technology, supervision, and work-group structures. Administrative Science Quarterly, 1974, 19, 395-410.

Inkson, J. H. K., Hickson, D. J., \& Pugh, D. S. Organizational context and structure: An abbreviated replication. Administrative Science Quarterly. 1970, 15, 318-329.

Jelinek, M. Technology, organizations, and contingency. Academy of Management Review, 1977, 2(1), 17-26.

Kast, F. E., \& Rosenzweig, J. E. General systems theory: Applications for organizations and management. Academy of Management Journal, 1972, 15, 447-465.

Katz, D., \& Kahn, R. L. The social psychology of organizations (2nd ed.). New York: Wiley, 1978.

Khandwalla, P. N. Mass output orientation of operations technology and organizational structure. Administrative Science Quarterly, 1974, 19, 74-97.

Lawrence, P. R., \& Lorsch, J. W. Organizations and environment. Homewood, III.: Irwin, 1969.

Lynch, B. P. An empirical assessment of Perrow's technology construct. Administrative Science Quarterly, 1974, 19, 338-356.

Mahoney, T. A., \& Frost, P. J. The role of technology in models of organizational effectiveness. Organizational Behavior and Human Performance, 1974, 11, 122-138.

Mohr, L. B. Organizational technology and structure. Administrative Science Quarterly, 1971, 16, 444-459.

Montanari, J. R. Managerial discretion: An expanded model of organization choices. Academy of Management Review, 1978, 3, 231-241.

Morrissey, E., \& Gillespie, D. F. Technology and the conflict of professionals in bureaucratic organizations. The Sociological Quarterly, 1975, 16, 319-332.

Newman, W. H. Strategy and management structure. Journal of Business Policy, 1971, 2, 56-66.

Overton, P., Schneck, R., \& Hazlett, C. B. An empirical study of the technology of nursing subunits. Administrative Science Quarterly, 1977, 22, 203-219.

Peterson, R. B. The interaction of technological process and perceived organizational climate in Norwegian firms. Academy of Management Journal, 1975, 18, 288-299.

Randolph, W. A., \& Finch, F. E. The relationship between organization technology and the direction and frequency dimensions of task communications. Human Relations, 1977, 30, 1131-1145.
Reimann, B. C. Dimensions of technology and structure: An exploratory study. Human Relations, 1977, 30, 545-566.

Roberts, K. H. On looking at an elephant: An evaluation of cross-cultural research related to organizations. Psychological Bulletin, 1970, 74, 327-350.

Rousseau, D. M. Technological differences in job characteristics, employee satisfaction, and motivation: A synthesis of job design research and sociotechnical systems theory. Organiza. tional Behavior and Human Performance, 1977, 19, 18-42.

Rousseau, D. M. Characteristics of departments, positions, and individuals: Contexts for attitudes and behavior. Administrative Science Quarterly, 1978, 23, 521-540. (a)

Rousseau, D. M. Measures of technology as predictors of employee attitude. Journal of Applied Psychology, 1978, 63, 213 . 218. (b)

Rousseau, D. M. Technology as an organizational strategy. Unpublished manuscript, 1978. (c)

Rushing, W. A. Hardness of material as related to division of labor in manufacturing industries. Administrative Science Quar. terly, 1968, 13, 229-245.

Scott, W. R. Organizational structure. Annual Review of Sociology, 1975, 1, 1-20.

Shepard, J. W. Technology, alienation, and job satisfaction. Annual Review of Sociology, 1977, 3, 1-21.

Stanfield, G. G. Technology and organizational structure as theoretical categories. Administrative Science Quarterly, 1976, 21, 489-493.

Taylor, F. Scientific management. New York: Harper, 1974.

Taylor, J. C. Some effects of technology in organizational change. Human Relations, 1971, 24, 105-123.

Thompson, J. D. Organizations in action. New York: McGrawHill, 1967.

Van de Ven, A. H., \& Delbecq, A. L. A task contingent model of work unit structure. Administrative Science Quarterly, 1974, 19, 183-197.

Wieland, G. F., \& Ullrich, R. A. Organizations: Behavior, design, and change. Homewood, III.: Irwin, 1976.

Woodward, J. Management and technology. London: Her Majesty's Stationery Office, 1958.

Woodward, J. Industrial organizations: Theory and practice. London: Oxford, 1965.

Zwerman, W. L. New perspectives on organization theory. Westport, Conn.: Greenwood, 1970.

Denise M. Rousseau is an Assistant Professor in the

Department of Administrative Sciences at the Naval

Postgraduate School, Monterey, California.

Received 11/27/78 